\title{
EDUKASI TIPS MENINGKATKAN DAYA TAHAN TUBUH DI MASA PANDEMI COVID-19 DI RT 16 KELURAHAN PULOKERTO KECAMATAN GANDUS PALEMBANG
}

\author{
Sintiya Halisya Pebriani ${ }^{1^{*}}$, Lily Marleni ${ }^{2}$, Mardiah $^{3}$, Adi Saputra ${ }^{4}$, M. Sharpone \\ Widodo $\mathrm{M} \mathrm{H}^{5}$, Derbi Ameliantri ${ }^{6}$, Endang Kusfarini ${ }^{7}$ \\ Program Studi DIII Keperawatan STIK Siti Khadijah Palembang \\ Email Korespondensi: Sintiyahp88@gmail.com
}

Disubmit: 30 September 2021 Diterima: 04 Desember $2021 \quad$ Diterbitkan: 01 Januari 2022

DOI: https://doi.org/10.33024/jkpm.v1i1.5218

\begin{abstract}
ABSTRAK
Di era pandemi Covid-19 seperti sekarang ini menjaga kesehatan sangatlah penting guna mencegah penularan penyakit tersebut. Selain melakukan protokol kehatan dengan baik dan benar, upaya yang sangat penting dalam mencegah penularan penyakit ini adalah dengan peningkatan imunitas tubuh agar tidak mudah terserang virus, sebagaimana diketahui virus Covid-19 menyerang kekebalan tubuh sehingga tubuh tidak mampu melawan virus ini. Tujuan dari pengabdian masyarakat ini yaitu masyarakat mengetahui bagaimana cara meningkatkan daya tahan tubuh di masa pandemi covid-19 sehingga terhindar dari penularan penyakit ini. Metode yang dilakukan berupa penyuluhan kesehatan tentang tips meningkatkan daya tahan tubu dimasa pandemic covid-19 dengan menggunakan media leaflet dan poster. Hasil penyuluhan menunjukkan masyarakat setempat memahami cara-cara meningkatkan daya tahan tubuh dimasa pandemi. Kesimpulan terdapat peningkatan pengetahuan masyarakat tentang cara menjaga dan meningkatkan daya tahan tubuh. Diharapkan dengan kegiatan ini masyarakat dapat menerapkan tips meningkatkan daya tahun tubuh dalam kehidupan sehari-hari.
\end{abstract}

Kata kunci : Edukasi, Daya tahan tubuh, Covid-19

\begin{abstract}
In the current era of the Covid-19 pandemic, maintaining health is very important to prevent the transmission of the disease. In addition to carrying out health protocols properly and correctly, a very important effort in preventing the transmission of this disease is to increase the body's immunity so that it is not susceptible to viruses, as it is known that the Covid-19 virus attacks the body's immunity so that the body is unable to fight this virus. The purpose of this community service is that the community knows how to increase their immune system during the COVID-19 pandemic so as to avoid the transmission of this disease. The method used is in the form of health education on tips to increase body resistance during the covid-19 pandemic by using leaflets and posters. The results of the counseling show that the local community understands ways to increase their immune system during the pandemic. The conclusion is that there is an increase in public knowledge about how to maintain and increase body resistance. It is hoped that with this activity the community can apply tips to increase the body's power in their daily lives.
\end{abstract}

Keywords: Education, immune system, Covid-19 


\section{PENDAHULUAN}

Di era pandemi Covid-19 seperti sekarang ini menjaga kesehatan sangatlah penting guna mencegah penularan penyakit tersebut. WHO sudah menetapkan bahwa covid-19 atau yang lebih dikenal dengan Coronavirus Disease merupakan Public Health Emergency of International Concern (PHEIC) atau Kedaruratan Kesehatan Masyarakat Yang Meresahkan Dunia (KKMMD) yang sekarang virusnya sudah menyebar ke berbagai negara (WHO, 2020).

Covid-19 adalah penyakit yang disebabkan oleh turunan coronavirus jenis baru yang terkait dengan keluraga virus yang sama dengan Servere Acute Respiratory Syndrome (SARS). Virus ini diketahui bermula dari Wuhan, Tiongkok yang ditemukan pada akhir Desember tahun 2019 (WHO, 2020). Tanda dan gejala umum pada penyakit ini antara lain gejala gangguan pernapasan akut seperti demam, batuk dan sesak napas. Pada kasus yang lebih berat infeksi Covid-19 dapat menyebabkan pneumonia, sindrom pernapasan akut, gagal ginjal, dan bahkan kematian (Kemenkes RI, 2020).

Penyebaran virus ini dapat ditularkan melalui kontak langsung dengan percikan batuk atau bersin (droplet) yang dikeluarkan oleh orang yang terinfeksi Covid-19, dan berdasarkan bukti ilmiah penyakit ini tidak dapat menyebar melalui udara (Kemenkes RI, 2020). Selain itu orang juga dapat terinfeksi jika menyentuh permukaan yang terkontaminasi oleh virus ini kemudian dengan sengaja atau tanpa sengaja menyentuh mata, hidung dan mulut (WHO, 2020).

Sampai saat ini jumlah penderita Covid-19 terus meningkat dari hari ke hari. Di Indonesia sendiri jumlah kasus positif Covid-19 pertanggal 27 Juni 2021 mengalami lonjakan tinggi, dengan jumlah penambahan kasus sebanyak 21.342 orang. Sehingga total akumulatif sebanyak 2.115.304 orang di Indonesia terkonfirmasi positif Covid-19. Provinsi Sumatera Selatan juga menunjukkan hal yang sama dimana jumlah kasus positif covid-19 mengalami kenaikan 18,1\% dengan jumlah kasus 28.177 kasus, dimana sebesar $53,69 \%$ kasus covid-19 berasal dari kota Palembang (Satgas Covid-19, 2021). Kota Palembang sendiri jumlah kasus konfimasi sebanyak 15.122 kasus (Dinkes Palembang). Hal ini menyebabkan Provinsi Sumatera Selatan berstatus zona merah, dimana insiden kasus tertinggi dimiliki Kota Palembang. Mengingat insiden Covid-19 yang terus meningkat dan bahaya yang ditimbulkan, maka perlu dilakukan tindakan tentang pencegahan penyebaran Covid-19 agar dapat memutuskan rantai penularan penyakit ini, sehingga akan meningkatkan kualitas hidup masyarakat.

Berbagai cara telah dilakukan oleh pemerintah maupun masyarkat untuk mengendalikan penyebaran virus ini dimana pemerintah telah menghimbau seluruh masyarakat untuk melakukan berbagai langkah pencegahan seperti pysical distansing, menggunakan masker, rutin mencuci tangan, meningkatkan menjaga kesehatan dan daya tubuh (Sari, 2020). Selain upaya-upaya tersebut, hal yang sangat penting lainya yaitu peningkatan imunitas tubuh agar tidak mudah terserang virus, sebagaimana diketahui virus Covid-19 menyerang kekebalan tubuh sehingga tubuh tidak mampu melawan virus ini (Mustofa \& Suhartatik, 2020).

Daya tahan tubuh tidak hanya mencegah terjangkitnya suatu penyakit, tetapi juga mempercepat proses penyembuhan dan pemulihan dari penyakit tertentu (Adisty et al., 2020). Fungsi sistem imun merupakan bagian penting dan perlu selalu dijaga agar daya tahan tubuh tetap kuat dan optimal. Sistem imun yang kuat sangat penting bagi pertahanan tubuh dalam mencegah berbagai penyakit menular, terutama di masa pandemi Covid-19 (Setyoningsih et al., 2021). Pada penelitian Azrimadaliza et al., (2021) ditemukan perilaku responden mengenai upaya gizi dalam meningkatkan imunitas tubuh selama pandemic Covid-19 
kategori rendah ( $>55 \%$ ). Pengetahuan yang baik akan menciptakan perilaku yang baik pula. Oleh karena itu diperlukan sosialisasi dan edukasi untuk meningkatkan pengetahuan dan pemahaman masyarakat tentang peningkatakan imunitas tubuh di masa pandemic Covid-19 yaitu salah satunya dengan melakuakn penyuluhan untuk membagikan informasi terkait Covid-19 kepada publik terutama masyarakat untuk menambah pengetahuan yang dapat mempengaruhi seseorang dalam berperilaku sehari-hari (Adijaya \& Bakti, 2021).

\section{MASALAH}

Kelurahan Pulo kerto merupakan salah satu dari lima kelurahan yang ada dalam wilayah kecamatan Gandus Kota Palembang. Berdasarkan kondisi geografis kelurahan Pulo Kerto memiliki luas $\pm 34.19 \mathrm{Km}^{2}$, adapun batas wilayah kelurahan gandus dapat dilihat yaitu : sebelah utara berbatasan dengan Kecamatan Talang Kelapa (Kabupaten Banyuasin), sebelah barat berbatasan dengan Kecamatan Gelumbang, sebelah Selatan berbatasan dengan Kecamatan Banyuasin III, sebelah timur berbatasan dengan Kelurahan Gandus. Berdasarkan letak geografisnya kelurahan Pulo Kerto merupakan daerah pinggiran kota sehingga masyarakat disini membutuhkan pengetahuan tentang kesehatan terutama di masa pandemi Covid-19 guna mempertahankan dan meningkatkan derajat kesehatan masyarakat. Upaya peningkatan kesehatan yang dapat dilakukan adalah dengan melakukan berbagai kegiatan, salah satunya adalah kegiatan penyuluhan untuk dapat memberikan informasi yang ilmiah kepada seluruh lapisan masyarakat mengenai pencegahan virus covid-19 dengan tips meningkatkan daya tahan tubuh. Pengetahuan dan pemahaman yang baik, akurat dan dapat dipercaya akan dapat membantu masyarakat untuk mudah melaksanakan himbuan dan arahan pemerintah guna menekan penyebaran Covid19.

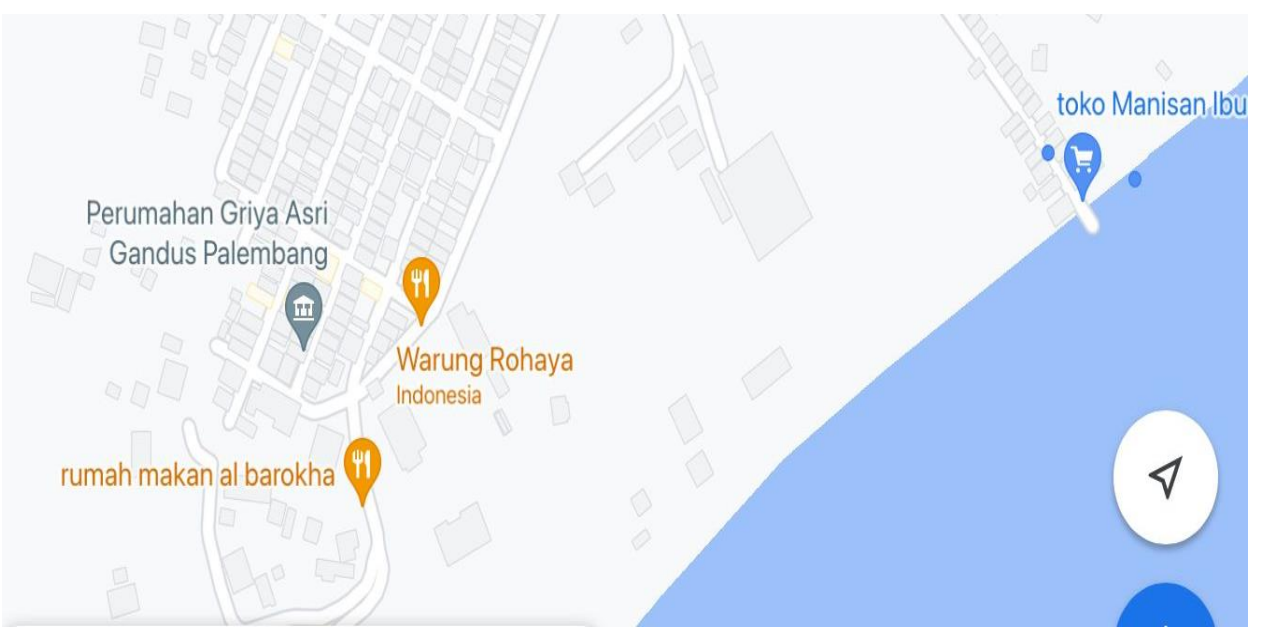

Gambar 1. Peta Lokasi Kegiatan Pengabdian Masyarakat (Kelurahan Puloketo Kecamatan Gandus)

\section{METODE}

a. Tahap Persiapan

Tahap persiapan dari kegiatan ini adalah melakukan survei lapangan ke lokasi oleh tim pengabdian masyarakat. Kemudian melakukan pendekatan kepada Ketua RT 16 dengan mengirimkan permohonan ijin pelaksanaan kegiatan pengabdian masyarakat serta koordinasi untuk menentukan 
jadwal penyelenggaraan penyuluhan. Tahap selanjutnya yaitu persiapan media penyuluhan berupa leaflet dan poster.

b. Tahap Pelaksanaan

Tahap pelaksanaan diawali dengan koordinasi dengan ketua RT untuk mengumpulkan warga stempat. Setelah itu tim melakukan penyuluhan tentang cara-cara meningkatkan daya tahan tubuh di masa pandemic covid-19 dengan menggunakan leaftet dan poster. Sebelum dilakukan penyuluhan dilakukan pre-test kepada warga setempat. Selama penyuluhan dilakukan, peserta sangat antusias menyimak dan bertanya. Dan setelah penyuluhan berakhir tim melakukan evaluasi Kembali berupa post-test kepada peserta untuk melihat seberapa meningkatnya pengetahuan dan pemahaman peserta mengenai tips meningkatkan daya tahan tubuh di masa pandemic covid-10. Kegiatan ini berlangsung pada tanggal 10 Juli 2021 dari pukul $09.00 \mathrm{wib}-11.00 \mathrm{wib}$.

c. Tahap Evaluasi

1) Struktur

Kegiatan pengabdian masyarakat dilaksanakan sesuai dengan jadwal yang sudah ditetapkan, berlangsung dengan baik dan diahadiri oleh 16 warga setempat. Materi penyuluhan disampaikan dengan menggunakan bahasa sederhana dan mudah di mengerti oleh para peserta. Peserta dapat memahami materi penyuluhan yang sudah diberikan, dan peserta juga antusias bertanya dan melakukan diskusi dengan tim pengabdian.

2) Proses

Pelaksanaan kegiatan ini dimulai dari pukul 09.00 wib - 11.00 wib. Sesuai dengan jadwal yang sudah direncanakan.

\section{HASIL DAN PEMBAHASAN}

a. Hasil

Proses pelaksanaan dalam kegiatan Penyuluhan dengan tema Tips Meningkatkan Daya Tahan Tubuh di Masa Pandemi Covid-19 di RT.16 Kelurahan Pulokerto Kecamatan Gandus Palembang Tahun 2021 telah dilaksanakan pada tanggal 10 Juli 2021. Kegiatan berlangsung dari pukul 09.00- 11.00 wib. Pelaksanaan penyuluhan ditujukan pada masyarakat setempat dengan media dan alat yang digunakan yaitu leaflet dan poster. Penyampaian materi dengan metode ceramah dan diskusi mengenai tips-tips dalam meningkatkan daya taha tubuh dimasa pandemi seperti dengan mengkonsumsi makanan yang bergizi dengan perbanyak mengkonsumsi buah dan sayur, cukup tidur/istirahat, melakukan aktivitas fisik atau olahraga, menjaga jarak fisik dari orang lain, dan menerapkan pola hidup bersih dan sehat.

Pada saat materi berakhir di berikan follow up ke masyarakat yang mengikuti penyuluhan dengan mudah mereka bisa menjawab pertanyaan-pertanyaan yang di berikan serta ada beberapa masyarakat memberikan pertanyaan terkait hal yang belum mereka pahami, kegiatan ini harapannya ke depan bisa dilaksanakan secara berkesinambungan karena memang lokasi kegiatan penyuluhan ini merupakan lokasi desa binaan prodi DIII keperawatan. Berikut gambar pelaksanaan penyuluhan yang telah di lakukan: 

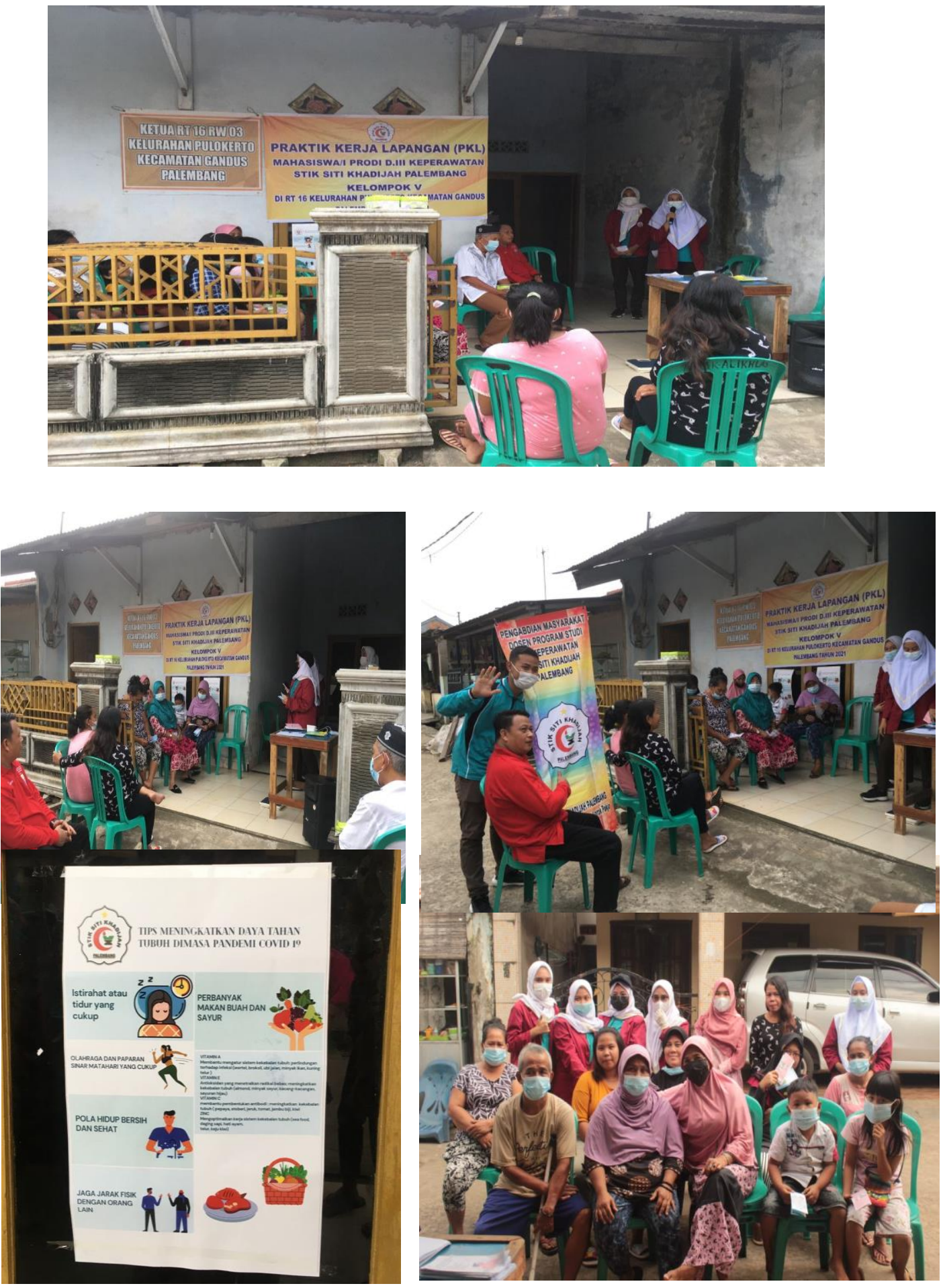

Gambar 4.1 Pelaksanaan Kegiatan Pengabdian Masyarakat

\section{b. Pembahasan}

Kegiatan penyuluhan ini merupakan salah satu upaya untuk memutus rantai penyebaran Covid-19 dengan cara meningkatan pemahaman dan pengetahuan serta perilaku yang baik dan benar dari seluruh masyarakat tentang menjaga dan meningkatakan daya tahan tubuh guna mencegah infeksi Covid-19. Pada 
dasarnya, tubuh manusia memiliki sistem imun untuk melawan virus dan bakteri penyebab penyakit. Namun daya tahan tubuh tersebut dapat melemah oleh berbagai hal seperti penuaan, kurang gizi, penyakit, bahkan obat-obatan tertentu. Untuk itu, fungsi sistem imun perlu senantiasa dijaga agar daya tahan tubuh kuat. Sistem imun yang kuat sangat penting bagi tubuh mencegah berbagai penyakit, terutama di masa pandemi COVID-19 (Setyoningsih et al., 2021).

Menjaga imunitas tubuh di masa pandemi sangat penting dalam mencegah infeksi Covid-19. Peningkatkan daya tahan tubuh dapat diperoleh dengan mudah, yaitu cukup melakukan aktivitas fisik secara rutin dan teratur dan diimbangi dengan asupan nutrisi yang baik (Adijaya \& Bakti, 2021). Banyak manfaat yang diperoleh dari melakukan aktivitas fisik secara rutin dan teratur, salah satunya dapat menjaga kebugaran dan fungsi organ di dalam tubuh (Palar et al., 2015). Dengan rutin beraktivitas fisik seperti berolahraga secara rutin dapat menstimulus antibodl dan sel-sel darah putih bersirkulasi lebih cepat (Gleeson et al., 2013). Dalam peningkatan imunitas tubuh diperlukan aktivitas fisik dengan intensitas sedang dengan durasi kurang dari 60 menit, dimana dengan intensitas sedang akan menstimulasi imunitas seluler (Tiksnadi et al., 2020).

Selain itu kunci lain untuk mempertahankan daya tahan tubuh adalah dengan asupan gizi yang berperan penting dalam fungsi imunitas tubuh. Asupan zat gizi makro seperti protein berperan dalam pembentukan immunoglobin, dan asam lemak tidak jenuh ganda (poly unsaturated fatty acid) terutama omega 3 berpedan dalam menurunkan inflamasi. Disamping itu asupan gizi mikro juga berperan penting dalam peningkatan imunitas tubuh dalam melawan infeksi virus seperti vitamin C, Vitamin D, Vitamin A, Vitamin B6 dan b12 serta zat besi (fe) dan selenium (Se) (Adijaya \& Bakti, 2021). Butler-Laporte et al., (2021) juga menjelaskan mengkonsumsi makanan kaya vitamin dan mineral dapat membantu tubuh tetap sehat guna melawan virus dan bakteri penyebab penyakit. Sistem imunitas yang baik bergantung pada diet sehat yang seimbang dari waktu ke waktu. Untuk mencegah infeksi virus Covid-19, juga dapat didukung dengan konsumsi suplemen yang dapat memperkuat daya tahan tubuh. Kandungan vitamin dan mineral dalam suplemen, seperti vitamin $C$ (sodium ascorbate), vitamin B3 (nicotinamide), vitamin B5 (dexpanthenol), vitamin B6 (pyridoxine $\mathrm{hcl}$ ), vitamin $\mathrm{E}$ (alpha tocopheryl), zinc picolinate, dan sodium selenite, dapat meningkatkan kinerja sistem imun dalam melawan infeksi yang disebabkan oleh virus maupun bakteri, termasuk infeksi virus Corona. Di sisi lain, vitamin B3, B5, dan B6 dapat memperbaiki sel-sel tubuh yang rusak akibat sakit.

Selain memperkuat daya tahan tubuh dengan beragam cara di atas, juga perlu menerapkan pola hidup sehat lainnya, seperti berhenti merokok, mengurangi minum minuman beralkohol, hindari stress, minum air putih yang cukup, cukup tidur/istirahat, serta menjaga jarak fisik dari orang lain.

\section{KESIMPULAN}

Pengabdian masyarakat dengan topik "Tips Meningkatkan Daya Tahan Tubuh di Masa Pandemi Covid-19 di RT.16 Kelurahan Pulokerto Kecamatan Gandus Palembang Tahun 2021" telah terlaksana dengan baik. Masyarakat setempat telah mendapatkan penyuluhan dan penjelasan yang jelas dan mudah dipahami mengenai tips meningkatkan daya tahan tubuh di masa pandemi. Dengan adanya kegiatan penyuluhan ini terjadi peningkatan pengetahuan masyarakat tentang cara-cara menjaga dan meningkatakan sistem imun di masa pandemic. 


\section{DAFTAR PUSTAKA}

Adijaya, O., \& Bakti, A. P. (2021). Peningkatan Sistem Imunitas Tubuh dalam Menghadapi Pandemi COVID-19. Jurnal Kesehatan Olahraga.

Adisty, H., Amalia, R., Destanto, R., Anan, Y., Susweni, R., \& Apriana, D. (2020). Sosialisasi Meningkatkan Imunitas Tubuh Anak Dalam Menghadapi COVID-19 Dengan Pola Makan Sehat dan Bergizi. Universitas Negeri Semarang.

Azrimadaliza, A., Khairany, Y., \& Putri, R. (2021). Pengetahuan, Sikap dan Perilaku Gizi Keluarga dalam Meningkatkan Imunitas Selama Pandemi Covid19. Jurnal Ilmiah Kesehatan, 20(1). https: / /doi.org/10.33221/jikes.v20i1.883

Butler-Laporte, G., Nakanishi, T., Mooser, V., Morrison, D. R., Abdullah, T., Adeleye, O., Mamlouk, N., Kimchi, N., Afrasiabi, Z., Rezk, N., Giliberti, A., Renieri, A., Chen, Y., Zhou, S., Forgetta, V., \& Brent Richards, J. (2021). Vitamin D and COVID-19 susceptibility and severity in the COVID-19 host genetics initiative: A Mendelian randomization study. PLoS Medicine, 18(6). https://doi.org/10.1371/journal.pmed.1003605

Gleeson, M., Bishop, N., \& Walsh, N. (2013). Exercise Immunology. In Exercise Immunology. https://doi.org/10.4324/9780203126417

Kemenkes RI. (2020). Pedoman Pencegahan dan Pengendalian Coronavirus Disease (COVID-19). Germas.

Mustofa, A., \& Suhartatik, N. (2020). Meningkatkan Imunitas Tubuh Dalam Menghadapi Pandemi Covid-19 Di Karangtaruna Kedunggupit, Sidoharjo, Wonogiri, Jawa Tengah. Selaparang Jurnal Pengabdian Masyarakat Berkemajuan, 4(1). https://doi.org/10.31764/jpmb.v4i1.3100

Palar, C. M., Wongkar, D., \& Ticoalu, S. H. R. (2015). Manfaat Latihan Olahraga Aerobik Terhadap Kebugaran Fisik Manusia. Jurnal E-Biomedik, 3(1). https://doi.org/10.35790/ebm.3.1.2015.7127

Sari, M. K. (2020). Sosialisasi tentang Pencegahan Covid-19 di Kalangan Siswa Sekolah Dasar di SD Minggiran 2 Kecamatan Papar Kabupaten Kediri. Jurnal Karya Abdi, 4(1).

Setyoningsih, H., Pratiwi, Y., Rahmawati, A., Wijaya, H. M., Lina, R. N., \& Kudus, K. (2021). Penggunaan Vitamin Untuk Meningkatkan Imunitas Tubuh di Masa Pandemi. Jurnal Pengabdian Kesehatan, 4(2), 136-150.

Tiksnadi, B. B., Sylviana, N., Cahyadi, A. I., \& Undarsa, A. C. (2020). Olahraga Rutin untuk Meningkatkan Imunitas Pasien Hipertensi Selama Masa Pandemi COVID-19. Indonesian Journal of Cardiology, 41(2). https: / / doi.org/10.30701/ijc.1016

WHO. (2020a). Coronavirus disease (COVID-19) outbreak. Emergencies Diseases.

WHO. (2020b). Pesan dan Kegiatan Utama Pencegahan dan Pengendalian COVID19 di Sekolah. Unicef. 